\title{
Clinical Study of Dorsal Ligamentum Flavum Hypertrophy with Compressive Myelopathy and its Management
}

\author{
Authors \\ Dr Gitanjali Datta ${ }^{1}$, Gaurav Srivastav ${ }^{2}$, Sabyasachi Saha ${ }^{3}$, \\ Prateek Kumar Gupta ${ }^{4}$, Shri Ram Gupta \\ ${ }^{1}$ Assistant Professor, Neurosurgery, BIN and IPGME\&R Kolkata \\ 2,3,4,5 Resident, MCh Neurosurgery, BIN and IPGME\&R Kolkata \\ Corresponding author \\ Dr Gitanjali Datta
}

\section{Introduction}

Ossification of ligamentum flavum (OLF) is a well-known cause of progressive thoracic myelopathy reported in Japanese patients also series are reported from Korea, China, India, Middle East, and Caribbean with sporadic case reports in Caucasians ${ }^{(1)}$. It commonly involves lower thoracic spine (T9-T12) with upper thoracic spine (T1-T4) being the next common site. With the increased use of CT and MRI, ossification or hypertrophy of the ligamentum flavum (OLF) is gradually being recognized as a major cause of acquired thoracic spinal canal stenosis. Spinal cord compression by OLF is more common than by herniated intervertebral discs ${ }^{(3)}$. Posterior decompression by laminectomy is most commonly used. Patients present in variable neurological state. This study aimed at prospective analysis of data of 14 Indian patients who underwent surgical or conservative management for dorsal ligamentum flavum hypertrophy with compressive myelopathy. Correlation of various clinical and magnetic resonance imaging (MRI) parameters and preoperative neurological status and recovery studied.

\section{Patients and Method}

Fourteen patients with thoracic myelopathy due to OLF were studied out of which 7 underwent decompressive laminectomy and excision of the ligamentum flavum rest were treated on conservative basis as they didn't give consent for operation. Their MRI delineated a linear or beak like excrescence, uniformly hypo-intense on T1 and T2 weighted images, situated posterior to the thecal sac

\section{Results}

There was postoperative neurological deterioration in 5 patients and 9 patients improved in post op period. All the patients were discharged on the 7th postoperative day. On discharge, there was significant improvement in spasticity and tingling sensations of the lower limbs. At follow up, the patients had shown improvement in spasticity and power. However, all of them had residual spasticity so that none of them was able to run briskly. 
Summary of Patients with Ossified Ligamentum Flavum Causing Thoracic Compressive Myelopathy

\begin{tabular}{|c|c|c|c|c|c|}
\hline No. & AGE/SEX & CLINICAL & DURATION & $\begin{array}{l}\text { RADIOLOGY } \\
\text { (MRI) }\end{array}$ & SURGERY \\
\hline 1 & $45 / \mathrm{F}$ & $\begin{array}{l}\text { B/L LL spastic paraparesis, } \\
\text { urine incontinence }\end{array}$ & $3 \mathrm{yrs}$ & D10-11 OLF & $\begin{array}{c}\text { D10-11 laminectomy with } \\
\text { excision of flavum }\end{array}$ \\
\hline 2 & $49 / \mathrm{f}$ & $\begin{array}{l}\text { B/L LL spastic paraparesis, } \\
\text { urine incontinence }\end{array}$ & $1 \mathrm{yr}$ & $\begin{array}{l}\text { D1-2 } \\
\text { D2-3 } \\
\text { D9-10 }\end{array}$ & $\begin{array}{l}\text { D9-10 laminectomy with } \\
\text { excision of flavum }\end{array}$ \\
\hline 3 & $59 / \mathrm{m}$ & B/L LL weakness & 6 months & D9-10 & $\begin{array}{l}\text { D9-10 laminectomy with } \\
\text { excision of flavum }\end{array}$ \\
\hline 4 & $35 / \mathrm{m}$ & $\begin{array}{c}\text { Pain and tingling b/l LL with } \\
\text { gait imbalance }\end{array}$ & $2 y r s$ & D7-10 & Conservatively \\
\hline 5 & $25 / f$ & Spastic paraparesis & $1 \mathrm{yr}$ & D7-11 & \\
\hline 6 & $55 / \mathrm{m}$ & $\begin{array}{l}\text { LBP with b/l radiculopathy } \\
\text { with gait ataxia }\end{array}$ & $2 y r s$ & $\begin{array}{c}\text { D3-10 } \\
\text { Cervical pivd } \\
\text { Lumbar pivd }\end{array}$ & conservatively \\
\hline 7 & $60 / \mathrm{m}$ & $\begin{array}{l}\text { LBP with b/l radiculopathy } \\
\text { with gait ataxia }\end{array}$ & $1 \mathrm{yr}$ & $\begin{array}{c}\text { D9-12 } \\
\text { L5 over S1 } \\
\text { listesis grade } 1\end{array}$ & Conservatively \\
\hline
\end{tabular}

\begin{tabular}{|c|c|c|c|c|c|}
\hline 8 & $47 / \mathrm{m}$ & Spastic paraparesis & $2 \mathrm{yrs}$ & D7-10 & $\begin{array}{c}\text { D 7-10 laminectomy with } \\
\text { B/L D7-10TPSRF }\end{array}$ \\
\hline 9 & $23 / \mathrm{f}$ & Spastic paraparesis & $3 y r s$ & D8-11 & conservatively \\
\hline 10 & $38 / f$ & $\begin{array}{l}\text { Spastic paraparesis with urine } \\
\text { incontinence }\end{array}$ & $2 y r s$ & D9-10 & $\begin{array}{l}\text { D9-10 laminectomy with } \\
\text { excision of flavum }\end{array}$ \\
\hline 11 & $41 / \mathrm{f}$ & Spastic paraparesis & $10 y r s$ & D9-10 & conservatively \\
\hline 12 & $48 / \mathrm{m}$ & $\begin{array}{l}\text { Spastic paraparesis with urine } \\
\text { incontinence }\end{array}$ & 2months & D11 & $\begin{array}{l}\text { D11 laminectomy with } \\
\text { excision of flavum }\end{array}$ \\
\hline 13 & $32 / \mathrm{f}$ & $\begin{array}{l}\text { Spastic paraparesis with urine } \\
\text { incontinence }\end{array}$ & $5 y r s$ & $\begin{array}{l}\text { D3-4 } \\
\text { D7-8 } \\
\text { D9-11 }\end{array}$ & $\begin{array}{l}\text { D9-11 decompressive } \\
\text { laminectomy with } \\
\text { excision of flavum }\end{array}$ \\
\hline 14 & $53 / \mathrm{m}$ & $\begin{array}{l}\text { LBP with b/l radiculopathy } \\
\text { with gait ataxia }\end{array}$ & $2 y r s$ & $\begin{array}{c}\text { D5-6 } \\
\text { D9-10 }\end{array}$ & conservatively \\
\hline
\end{tabular}

\section{Discussion}

The ligamentum flavum is a yellowish elastic ligament extending form second cervical vertebra to the S1 segment of sacrum consisting of $80 \%$ elastin $^{(5)}$. The ligament is in the dorsal portion of the spinal canal, proximal insertion of ligamentum flavum is the ventral part of cranial lamina extending to the dorsal part of caudal lamina and extending to the capsules of facet joints and the posterior aspects of the neural foramina and is separated from the dura mater by epidural fat(9). LF is divided into two parts as a capsular portion and an inter-laminar portion. The mechanism of hypertrophy and progression of ossification is limited to the ligamentum flavum and neighboring spinal bony arch is spared ${ }^{(7)}$. The pathogenesis of ossified ligaments is not very clear. The various factors leading to ossification of LF include trauma, mechanical stress, diffuse idiopathic skeletal hyperostosis, ankylosing spondylitis, hemochromatosis, flourosis, growth factors (BMPs, VEGF9, TGF, Cartilage derived morphogenetic protein-1) and disorder of calcium and phosphorus ${ }^{(20)}$. Clinical manifestations and imaging tests are the two mainstays in the diagnosis. Local thoracic pain and slowly progressing spastic paraparesis are the distinctive features. Posterior cord syndrome includes loss of vibration and proprioception, develops in the early stage of disease process due to compression of the spinal cord from the posterior side. As the ossification progresses, the lateral corticospinal tracts begin to compress and then spastic paraparesis develops. Further extension leads to compression lateral spinothalamic tracts causing loss of sensation ${ }^{(24)}$.

The most common clinical manifestation at the time of the diagnosis is loss of functional gait. 
Radicular pain and loss of pain and temperature sensation are rare. Bladder disturbance is seen in late stages $^{(21)}$.

The role of radiologic studies is important in determining the etiology of myelopathy. CT remains the investigation of choice to demonstrate the characteristic contours and density of calcific changes (V shaped hyper-density). Spinal MRI shows hypertrophy of ligamentum flavum as dorso-lateral low signal mass appearance on both T1 \& T2 weighted images. T2 sagittal MRI is most useful in examining the whole spine and discovering multiple $\mathrm{OLFs}^{(26)}$. Posterior decompression with laminoplasty or laminectomy combined with lateral fusion is the mainstay treatment. For thoracic ossified ligamentum flavum fenestration or complete laminectomy are usually performed. The ossified ligament should be removed carefully taking care of ossified dura matter which usually concurs ${ }^{(5)}$.

This ossification of LF was reported to occur in up to $20 \%$ of Japanese individuals $>65$ years old and many reports viewed it as a normal feature of the ageing Asian spine ${ }^{(12)}$. The thickest OLF was located predominantly in the lower third of the thoracic spine (T9 to T12). This region is prone to degenerative processes due to the high tensile force present in the posterior column with associated kyphosis in the lower thoracic spine ${ }^{(15)}$. OLF occurred most frequently at the thoracolumbar junction due to unique orientation of the zygapophyseal joints that contributed to increased rotatory instability and micro motion ${ }^{(19)}$. The ligament hypertrophies and calcifies before it ossifies. High expression of transforming growth factor beta-1 (TGF- $\beta 1$ ) by fibroblasts was found in the ossified matrix within ossified ligaments and in chondrocytes within cartilaginous areas. TGF- $\beta 1$ might have played a role in chondroid metaplasia and ectopic ossification in $\mathrm{OLF}^{(17)}$.

On MRI DORSAL SPINE it appears as a linear or beak-like excrescence, uniformly hypointense on $\mathrm{T} 1$ and T2-weighted images, situated posterior to the thecal sac. T2-weighted MR imaging is particularly useful in showing the degree of spinal cord injury and the longitudinal extent and multiple sites of spinal cord compression. Also detects high-signal intramedullary cord intensity within the spinal cord on T2-weighted images that might indicate poor prognosis ${ }^{(18)}$. Early and prompt surgical intervention with appropriate rehabilitation plays key role in improving the functional outcome of myelopathy caused by $\mathrm{OLF}^{(23)}$. The prognosis after decompressive surgery can be good if intramedullary hyper intensities are absent on preoperative T2-weighted MR images. Posterior decompressive laminectomy with or without medial fascetectomy and removal of the ossified ligament are the most common surgical procedures performed in patients with dorsal ligamentum flavum hypertrophy with compressive myelopathy ${ }^{(14)}$. Laminoplasty with preservation of the posterior element after decompression can also be performed because of late neurological deterioration due to the recurrence of OLF at the same site or increased kyphotic deformity of the spine observed after laminectomy alone. Also there is no fusion after more than 1-level decompression $^{(6)}$.

\section{Bibliography}

1. Iguchi K, Kurokawa T, Nakamura K, Saita K, Miyoshi K, Takeshita K (1995) Surgical Outcomes Of Ossification Of Ligamentum Flavum of The Thoracic Spine, In Investigation Committee On Ossification Of Spinal Ligament. Japanese Ministry of Public Health and Welfare, Tokyo, pp 238-241 (in Japanese)

2. Ikeda K (2003) Treatment Of Thoracic Myelopathy Caused By Ossification Of The Spinal Ligaments. Yamaguchi Igaku 52:275- 283 (in Japanese)

3. Kawaguchi $\mathrm{Y}$, Kanamori M, Ishihara $\mathrm{Y}$, Nobukiyo M, Abe Y, Seki S (2004) Factors Related To Long-Term Outcome After Surgery For Ossification Of The Ligamentum Flavum Of The Thoracic Spine, In Investigation Committee On 
Ossification Of Spinal Ligament. Japanese Ministry of Public Health and Welfare, Tokyo, pp 118-123 (in Japanese)

4. Kawakami M, Tamaki T, Terao K, Hamazaki H, Ando M, Iwahashi T (1992) Analysis Of Neurological Symptoms And Clinical Results In Patients Surgically Treated For Ossification Of The Ligamentum Flavum. Sekitsui Sekizui 5:71-77 (in Japanese)

5. Kinjo Y, Sato S, Kise H, Takara H, Ibaraki K (1996) Surgical Result Of Thoracic Myelopathy With Ossification Of The Yellow Ligament, In Investigation Committee On Ossification Of Spinal Ligament. Japanese Ministry of Public Health and Welfare, 1996, Tokyo, pp 286289 (in Japanese)

6. Kohno Y, Hirofuji E, Nishimatsu $H$, Kondo K, Yoshida K (2001) The Clinical Results Of Kirita's Laminectomy For Ossification Of The Ligamentum Flavum In The Thoracic Spine. Chubu Rosaishi 44:1059-1060 (in Japanese)

7. Takei H, Hayashi M, Ito Y, Hashimoto J, Sagae M, Goto F et al (1997) Clinical Evaluations of The Surgical Treatment For Ossification of The Ligamentum Flavum. Rinsho Seikeigeka 32:13591365 (in Japanese)

8. Takei Y (1996) Posterior Decompression Surgery Of Thoracic Myelopathy Due To Ossification Of Intraspinal Canal Ligaments. J Tokyo Med Coll 54:253-263

9. Ueyama $K$, Harata $S$, Nitobe $T$, Iwata $D$, Okada A (1998) Long Term Results And Operative Methods Of Ossification Of The Ligamentum Flavum. Sekitsui Sekizui 11:511-516 (in Japanese).

10. Miyakoshi N, Shimada Y, Suzuki T, Hongo M, Kasukawa Y, Okada $\mathrm{K}$ et al (2003) Factors Related To Long-Term Outcome After Decompressive Surgery For Ossification Of The Ligamentum
Flavum Of The Thoracic Spine. J Neurosurg 99(3 Suppl):251-256

11. Shiokawa K, Hanakita J, Suwa H, Saiki M, Oda M, Kajiwara M(2001) Clinical Analysis And Prognostic Study Of Ossified Ligamentum Flavum Of The Thoracic Spine. J Neurosurg 94(2 Suppl): 221-226.

12. Chang UK, Choe WJ, Chung CK, Kim HJ (2001) Surgical Treatment For Thoracic Spinal Stenosis. Spinal Cord 39:362-369

13. Cho YH, Moon SM, Roh SW, Joen SR, Rhim SC (2002) Surgical Outcome And Prognostic Factors Of Ossified Ligamentum Flavum Of The Thoracic Spine. J Korean Neurosurg Soc 32:424430

14. Kuh SU, Kim YS, Cho YE, Jin BH, Kim KS, Yoon YS et al (2006) Contributing Factors Affecting The Prognosis Surgical Outcome For Thoracic OLF. Eur Spine J 15:485-491

15. Hur H, Lee JK, Lee JH, Kim JH, Kim SH (2009) Thoracic Myelopathy Caused By Ossification Of Ligamentum Flavum. J Korean Neurosurg Soc 46:189-194

16. He S, Hussain N, Li S, Hou T (2005) Clinical And Prognostic Analysis Of Ossified Ligamentum Flavum In A Chinese Population. J Neurosurg Spine $3: 348-354$

17. Liao CC, Chen TY, Jung SM, Chen LR (2005) Surgical Experience With Symptomatic Thoracic Ossification Of The Ligamentum Flavum. J Neurosurg Spine 2:34-39

18. Jayakumar PN, Devi BI, Bhat DI, Das BS (2002) Thoracic Cord Compression Due To Ossified Hypertrophied Ligamentum Flavum. Neurol India 50:286-289

19. Trivedi P, Behari S, Paul L, Banerji D, Jain VK, Chhabra DK (2001) Thoracic Myelopathy Secondary To Ossified Ligamentum Flavum. Acta Neurochir Wien 143:775-782 
20. Al-Orainy IA, Kolawole T (1998) Ossification Of The Ligament Flavum. Eur J Radiol 29:76-82

21. Ben Hamouda K, Jemel $H$, Haouet S, Khaldi M (2003) Thoracic Myelopathy Caused By Ossification Of The Ligamentum Flavum: a report of 18 cases. J Neurosurg 99(2 Suppl):157-161

22. Pascal-Moussellard H, Cabre P, Smadja D, Catonne Y (2005) Symptomatic Ossification Of The Ligamentum Flavum: a clinical series from the French Antilles. Spine 30:E400-E405

23. Shiraishi T, Crock HV, Lewis P (1995) Thoracic Myelopathy Due To Isolated Ossification Of The Liamentum Flavum. J Bone Join Surg Br 77:131-133

24. Vera CL, Cure JK, Naso WB et al (1997) Paraplegia Due To Ossification Of Ligamenta Flava In X-Linked Hypophosphatemia. A case report. Spine 22:710-715

25. Inamasu J, Guiot BH (2006) A Review Of Factors Predictive Of Surgical Outcome For Ossification Of The Ligamentum Flavum Of The Thoracic Spine. J Neurosurg Spine 5(2):133-139

26. Okada K, Oka S, Tohge K, Ono K, Yonenobu K, Hosoya T (1991) Thoracic Myelopathy Caused By Ossification Of The Ligamentum Flavum Clinicopathologic Study And Surgical Treatment. Spine 16:280-287

27. Ashworth B (1964) Preliminary Trial Of Carisoprodol In Multiple Sclerosis. Practitioner 192:540-542 28. Mehalic TF, Pezzuti RT, Applebaum BI (1990) Magnetic resonance imaging and cervical spondylotic myelopathy. Neurosurgery 26(2):217-226
28. Al-Mefty O, Harkey LH, Middleton TH, Smith RR, Fox JL (1988) Myelopathic Cervical Spondylotic Lesions Demonstrated By Magnetic Resonance Imaging. J Neurosurg 68(2):217-222

29. Kojima T, Oonishi I, Kurokawa T (1992) Ossification Of The Ligamentum Flavum In The Thoracolumbar Spine Of Young Adults: Report Of Two Cases. Int Orthop 16:75-79

30. Park BC, Min WK, Oh CW, et al. Surgical Outcome Of Thoracic Myelopathy Secondary To Ossification Of Ligamentum Flavum. Joint Bone Spine 2007;74:600-5. 